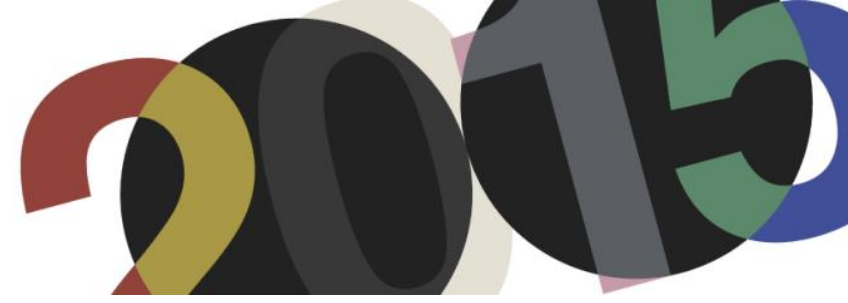

DOI: http://dx.doi.org/10.4995/LC2015.2015.679

\title{
Architecture as machine; Towards an architectural system for human well-being
}

\author{
P. Atmodiwirjo, Y.A. Yatmo
}

Department of Architecture, Faculty of Engineering, Universitas Indonesia

\begin{abstract}
Le Corbusier's well-known phrase 'The house is a machine for living in' suggested a kind of machinic aesthetic that became an important concept behind the functionality, standardization and rational order that together laid the foundation of modern architecture. This paper attempts to expand on Le Corbusier's idea of machine by particularly examining architecture as a machinic system and how it could potentially depict spatial qualities that fulfill their functional purpose for human well-being. The idea of machine became a way to introduce scientific and logical reasoning as the basis of designing architecture through the establishment of standards. There were, however, some criticisms against the idea of machine since it tends to dehumanize, by assuming that human being had the same basic needs that could be standardized. This paper attempts to highlight that the establishment of standard becomes necessary, not in generating standard architectural forms but in defining the performance standard of architecture for human well-being.
\end{abstract}

Resumen: Conocida frase de Le Corbusier 'The house is a machine for living in'sugiere una especie de estética maquínica que se convirtió en un concepto importante detrás de la funcionalidad, la normalización y el orden racional que juntos sentó las bases de la arquitectura moderna. En este trabajo se intenta ampliar la idea de Le Corbusier de máquina en particular examinar la arquitectura como un sistema maquínico y cómo se podría llegar a representar cualidades espaciales que cumplan su propósito funcional para el bienestar humano. La idea de la máquina se convirtió en una forma de introducir el razonamiento científico y lógico como base de diseño la arquitectura a través del establecimiento de normas. Hubo, sin embargo, algunas críticas contra la idea de la máquina, ya que tiende a deshumanizar, asumiendo que el ser humano tenía las mismas necesidades básicas que podrían ser estandarizados. Este trabajo trata de poner de relieve que el establecimiento de la norma hace necesario, no en la generación de formas arquitectónicas estándar, pero en la definición de la norma de rendimiento de la arquitectura para el bienestar humano.

Keywords: machine; system; standard; well-being; users.

Palabras clave: máquina; sistema; norma; bienestar; usuarios.

\section{Introduction}

The idea of architecture as machine was proposed by Le Corbusier particularly through his well-known statement 'The house is a machine for living in.' This phrase appeared in his writing Toward A New Architecture $^{1}$ to illustrate his argument that architecture should be designed in a way that refers to the engineers' working methods in problem solving and that it should be designed in accordance to standards. The idea that house should be designed following the same logic as the machine has led to the establishment of standardization in architecture, which Le Corbusier then also further extended into the standardization at the city scale. ${ }^{2}$ This paper attempts to expand on Le Corbusier's idea of machine by particularly examining how it could potentially depict the way architecture fulfills its functional purpose for human well-being.

\footnotetext{
${ }^{1}$ Le Corbusier. Towards a new architecture, New York: Dover Publication, 1986, p. 107

${ }^{2}$ Evenson, Norma. Le Corbusier: The machine and the grand design, London: Studio Vista, 1969
} 
The idea of machine was not exclusively proposed by Le Corbusier. Various works in architecture and other related disciplines has addressed both the abstract and concrete meanings of the machinic concepts, such as Guattari's desiring machine ${ }^{3}$ and Daniel Libeskind's reading, memory and writing machines ${ }^{4}$. Some works took further the idea of machine in architecture through the concepts such as mechanics and appliances, such as Nicholson's appliance house ${ }^{5}$ and Banham's idea of house as an ensemble of mechanical gadgetry ${ }^{6}$. These works suggest that the idea of machine involves the mechanisms of interface, complexity and causality, and therefore it provokes some critical ways of comprehending the relationship between elements involved in a system. To compare these ideas of machine with Le Corbusier's statement regarding architecture as machine is of course beyond the scope of this paper. Nevertheless these examples suggest the continuous attempts to think of architecture in a metaphoric way by referring to various properties associated with the machine.

Architecture as a machine could be understood as an assemblage of elements, as constituting different parts that together make up the whole system, as described in the following: 'To see dwelling as a machine in the manner of Deleuze and Guattari would also be essentially to make the same point as Le Corbusier: it would be an assemblage of elements coming together in a consistency, namely, the boundary of a dwelling. ... The house is something that is made up of a collection of elements which become significant when made into a whole. ...Both these notions of the machine, therefore, imply a form of determinism based on the material, of the machine as a limiting and containing form, which imposes an order and an organisation forced by the coming together of its constituent elements. ${ }^{7}$

This paper intends to further examine how Le Corbusier's idea of machine could explain how architecture is developed and realized as a working system, particularly to cater for the needs of its users. The relationship between the users and architecture incorporates complex relations that involve various bodily aspects of spatial experience, comfort and ergonomics as well as human desire and emotion. These are the bodily aspects that to some extent determine the well-being of the inhabitants. This paper argues that the idea of machine becomes a way to introduce scientific and rational approach as a basis of designing architecture through the establishment of standards, especially in designing domestic living space. The establishment of standard will be discussed by taking reference to some of Le Corbusier's writing and works, particularly The Manual of the Dwelling ${ }^{8}$ that $^{2}$ indicate the importance of standard in responding to the basic needs of human being. Meanwhile, there are some criticisms that the establishment of standard tends to assume that human being has the same basic needs that could be standardized. The paper will conclude that the establishment of standard becomes necessary, not in generating standard architectural forms but in defining the performance standard of architecture, which is eventually to promote the well-being of the users.

\footnotetext{
${ }^{3}$ Guattari, Felix. "On machines”. Journal of Philosophy and the Visual Arts, 1995, vol. 6, pp. 8-12

${ }^{4}$ Ioannidou, Ersi. "Humanist machines: Daniel Libeskind's 'Three lessons in architecture'”. In Bandyopadhyay, Soumyen et al (Eds.) The humanities in architectural design: A contemporary and historical perspective. Routledge: London, 2010, pp. 81-90

${ }^{5}$ Nicholson, Ben. Appliance house. MIT Press, 1990

${ }^{6}$ Banham, Reyner. "A home is not a house". Art in America, 1965, vol. 2, pp. 70-79

${ }^{7}$ King, Peter. In dwelling: Implacability, exclusion and acceptance. Hampshire, Ashgate, 2008, p. 50

${ }^{8}$ Le Corbusier. Towards a new architecture, New York: Dover Publication, 1986, p. 107
} 


\section{The establishment of architectural standard}

For Le Corbusier, the machine is a metaphor for architecture, through which the idea of functionality was established. The purpose of creating architecture as a machine for living is achieved by establishing a standard, with the primary goal to create order in human life and living space. 'The key modern principle for Le Corbusier was function, and this is where the machine metaphor is so important. The idea of the house as a machine is that it fulfills a specific function. ${ }^{, 9}$ In relation to architecture, Le Corbusier emphasized that in order to fulfill its functions, architecture should be consistently guided by certain standard. The establishment of standard is considered important because it would allow human to live better in a more orderly way, thus it becomes an important foundation from which good architecture could emerge.

The basis of defining the standard was the functionality. The idea of architecture as a machine indicated the importance of science and logic as a basis of designing architecture. Le Corbusier referred to the way engineers work in creating airplanes, automobiles and other machines; each problem was stated explicitly, and thus could be responded appropriately and correctly by the solutions. There was a logical process that existed beyond the creation of engineering products; 'the lesson of the airplanes lies in the logic that governed the enunciation of the problem and which led to its successful realization. When a problem is properly stated, in our epoch, it inevitably finds a solution. ${ }^{10}$ This is the way architecture should be created - through logical reasoning and establishment of standards. The standards were not established arbitrarily but through logical and scientific reasoning. 'A standard is established on sure bases, not capriciously but with the surety of something intentional and of a logic controlled by analysis and experiments... The establishment of standard involves exhausting every practical and reasonable possibility..."11 The above statement suggested a scientific way of thinking and its importance in the design process of architecture.

The idea of standard in architecture was developed by Le Corbusier through his project Maison Citrohan. The name Citrohan referred to Citroên, suggesting the idea that the house should be designed and produced as automobiles. ${ }^{12}$ Maison Citrohan was produced as a prototype of housing with standard building elements (Figure 1). The windows, doors and other elements should follow certain dimensions. The idea of standardization was further realized in many other projects such as the housing at Pessac, where the standardization of building elements became a method to achieve cheap and quick production of houses. All the dimensions of the doors, metal windows, roller blinds, staircases and fittings were all standardized and incorporated into the modular design process. ${ }^{13}$

\footnotetext{
${ }^{9}$ Ibid, p. 48

${ }^{10}$ Le Corbusier, Towards a new architecture, p. 110

${ }^{11}$ Ibid, p. 136

${ }^{12}$ Von Moos, Stanislaus, Le Corbusier: Elements of a synthesis, Rotterdam: 010 Publishers, 2009

${ }^{13}$ Tim Benton, 'Pessac and Lege revisited: Standards, dimensions, and failures.” In B. B. Taylor (ed.), Le Corbusier et Pessac, Paris: Fondation Le Corbusier, 1972
} 

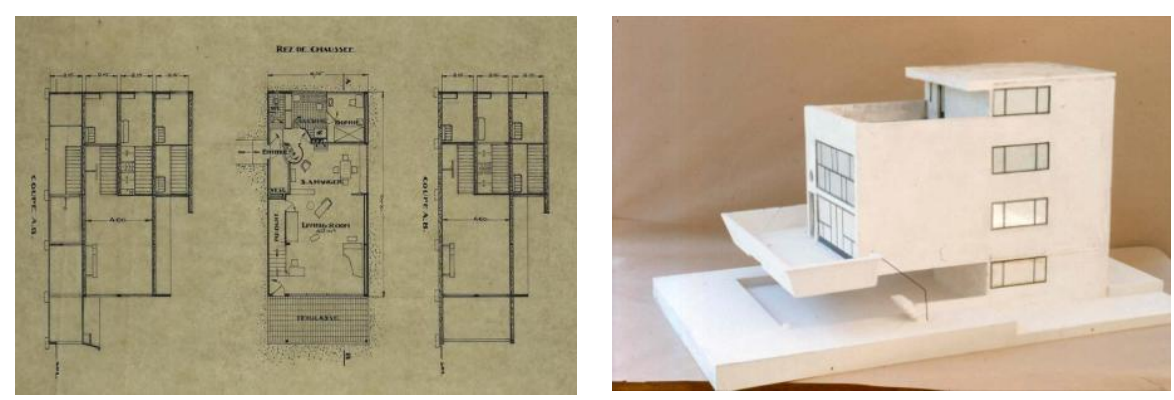

1. The model and plans of Maison Citrohan (Fondation Le Corbusier, image no. 20711 @ FLC-ADAGP).

The importance of such standards was further elaborated by Le Corbusier in the 'Manual of the Dwelling. ${ }^{14}$ In this manual, he listed the requirements of the house so that it could cater for the functional, everyday needs of the inhabitants. The manual was emerged from his criticism against inefficiency, uselessness of elements and other design mistakes that he observed in many of the houses at that period of time. He argues that the houses were not designed appropriately for modern living. As he stated: 'The existing plan of the dwelling-house takes no account of man and conceived as furniture store ${ }^{, 15}$ and thus a manual of dwelling is desperately needed. Included in this manual were the requirements and the elements that should be demanded by the house inhabitants, from the space requirements of the bedroom, bathroom, kitchen and living room, the needed household elements and furniture, and some other requirements.

The list was somewhat arbitrary, since it appears as 'a strange combination of functions, outcomes and aesthetic qualities. ${ }^{16}$ This arbitrarily could be observes in a portion of the following manual texts: 'If you can, put the kitchen at the top of the house to avoid smells. Demand concealed or diffuse lighting. Demand a vacuum cleaner. Buy only practical furniture and never buy "decorative" pieces. If you want to see bad taste, go into the houses of the rich. Put only a few pictures on your walls and none but the good ones. ${ }^{17}$ In this example, "to avoid smells' suggested the desirable condition for certain space, while 'demand concealed or diffuse lighting' referred to certain kind of lighting that is preferable - there was further explanation of why this kind of lighting was preferable somewhere else in the book. The suggestion 'demand a vacuum cleaner' had nothing to do with the design of the house but more on the needs for daily maintenance for cleanliness. Meanwhile the suggestion on the furniture and decoration refers to his disapproval against 'the house of the rich' which was usually full of decorative pieces with the walls full of pictures.

Observing the whole manual, we could observe that the list included the space requirements as well as suggestions of how to arrange the spaces: it included the desirable condition of the space as well as the suggestion of elements that should be provided. Nevertheless the manual had illustrated the importance of various functions that should be fulfilled by the dwelling in order to perform appropriately as human living space. Through the manual, Le Corbusier demonstrated how programmatic functionality became the main consideration from where the standardized requirements were derived and then used to design a proper house for living. This programmatic functionality incorporated the requirements for the space and the interior elements, the

\footnotetext{
${ }^{14}$ Le Corbusier, Towards a new architecture, pp. 122-123

${ }^{15}$ Ibid, p. 122

${ }^{16} \mathrm{King}$, In dwelling: Implacability, exclusion and acceptance, p. 49

${ }^{17}$ Le Corbusier, Towards a new architecture, p. 123
} 
standards for use and maintenance, as well as the economic propriety, which altogether defined what Le Corbusier conceived as the proper way of living for the modern era. ${ }^{18}$

\section{Standard for comfort and health}

Le Corbusier argued that the establishment of standard was a logical way to address the problem. Each of the requirements that were demanded in the Manual of the Dwelling illustrated an aspect of the dwelling space, and it was established for logical reasons and to address certain problems. The major problems identified by Le Corbusier, as he further explained, were primarily related to comfort and health. The demands for physical comfort constantly appeared in his works, especially in the established requirements for an open plan design which allowed for light and air to come through. It also appeared in the Manual of the Dwelling: 'the house is only habitable when it is full of light and air. ${ }^{19}$ Such openness as spatial properties was then developed into what was called the form language of modern architecture: 'One of the more important attributes of modern architecture style was the freedom it gave architects to plan the interior areas of buildings without regard to the previous conventions... With the new style, architects could open whole wall surfaces to light and air. ${ }^{20}$ The introduction of modern materials that allowed for larger span of space also meant possibility to have more open space design, which was open to light and air that functioned to provide comfort for the inhabitants.

The establishment of the standard for comfort was also developed in relation to the ergonomics of the furniture design. The idea of architecture as machine for living was extended to the furniture - 'Chairs are made to sit in. ${ }^{21}$ Le Corbusier emphasized the importance that chair should be appropriate for human body sitting on it, and he criticized the existing chairs in the houses, which did not give the best position for sitting. He attempted to understand different types of chairs in relation to human body ergonomics, ${ }^{22}$ and came up with a prototype of chair which he defined as appropriate - with attachment to hold a coffee cup, with a footrest, and with the body of chair adjustable to different positions depending on the sitting purpose. His works on furniture design indicated his attempts to state the problem of comfort in sitting and then to develop a logical solution to respond to such needs of comfort.

The establishment of architecture as machine with many standardized requirements was related not only to individual bodily comfort but also related to the wider issues of healthy living. 'Le Corbusier's famous machine a habiter was not only a machine for living in, but a technologically enhanced medical machine for healthier living. ${ }^{23}$ Many of the standards were necessary to be established in order to create architecture for healthy living. Architecture was considered essentially as a machine that could provide human with a new, hygienic environment for living. ${ }^{24}$ Awareness of how the climatic surrounding may affect the space became important. This was demonstrated for example in the works of Le Corbusier that incorporated the solarium to capture the

\footnotetext{
${ }^{18}$ Klingman, Anna. "Eyes, which do not see: Liners, airplanes, automobiles", Architectural Theory Review, vol. 9 no. 1 , 2004, pp. 19-35

${ }^{19}$ Ibid, p. 123

${ }^{20}$ Newman, Oscar. "Whose failure is modern architecture?” In Mikellides, Byron (Ed.), Architecture for people, New York: Holt. Rinehart \& Winston, 1980, p. 46

${ }^{21}$ Le Corbusier, Towards a new architecture, p. 117

${ }^{22}$ Benton, Charlotte, "Le Corbusier: Furniture and the interior". Journal of Design History, vol. 3, no. 2/3, 1990, p. 113

${ }^{23}$ Rault, Jasmine. Eileen Gray and the design of sapphic modernity: Staying in. Surrey, England: Ashgate, 2011, p. 34

${ }^{24}$ Smith, Wally \& Lewi, Hannah. "The magic of machines in the house," The Journal of Architecture, vol. 13, no. 5, pp. 633-660
} 
health benefits of sunshine, ${ }^{25}$ and those that explored the solar geometry in relation to the orientation of the design to capture the benefit of the light and air. ${ }^{26}$ Some of the spatial ideas of modern architecture were assumed to have been associated with the attempts to combat tuberculosis at that time, by providing access to light, air and sun through various architectural features: flat roofs, terraces, balconies, summer houses and reclining chairs. ${ }^{27}$ Some analytical diagrams were produced to indicate his concern towards the importance to establish the architectural system that could work to promote human comfort and healthy living.

It becomes clear that one of the main purposes in establishing the standard for architecture was to set criteria for architecture to function or perform appropriately to achieve human comfort and health and hygiene. The logical reasoning that became the basis of functional thinking was very useful in defining the problems and developing solutions as logical responses to the problems. Le Corbusier had demonstrated such scientific way of thinking in solving the problem of the dwelling at that time, and he attempted to create new modern living spaces which were governed by standards in order to achieve comfort, health and ergonomics of human as the users of architecture. Architecture as machine provided an idea of how architectural elements could become parts of a machinic system that responded to the problems of bodily comfort, ergonomics and health. However, it also raised a more fundamental question on the extent to which machinic properties of standardization could intersect with bodily-related purposes of architecture, in order to promote the role of architecture for human well-being, and we will turn to this issue in the following section.

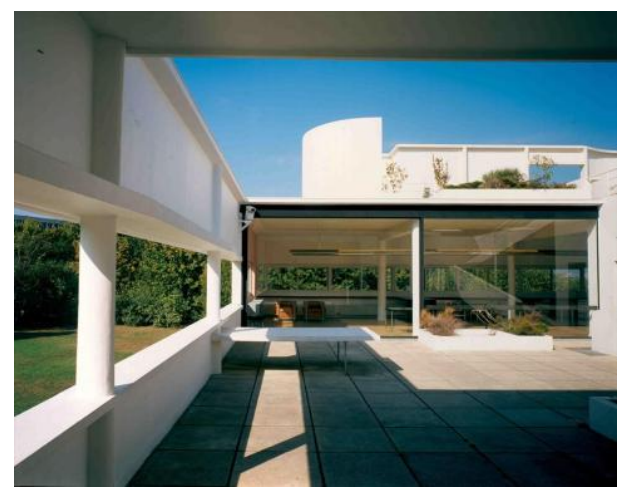

2. Some features of modern architecture that promote human comfort and health (Photo by Paul Kozlowski, Fondation Le Corbusier @FLC-ADAGP).

\footnotetext{
${ }^{25}$ Sully, Nicole. "Modern architecture and complaints about the weather, or, 'Dear Monsieur Le Corbusier, It is still raining in our garage...." M/C Journal, Vol. 12, No. 4, 2009

${ }^{26}$ Mackenzie, Christopher. "Le Corbusier in the sun”, The Architectural Review, June 2011

${ }^{27}$ Campbell, Margaret. "What tuberculosis did for modernism: The Influence of a curative environment on modernist design and architecture, Medical History, vol. 49, 2005, pp. 463-488
} 

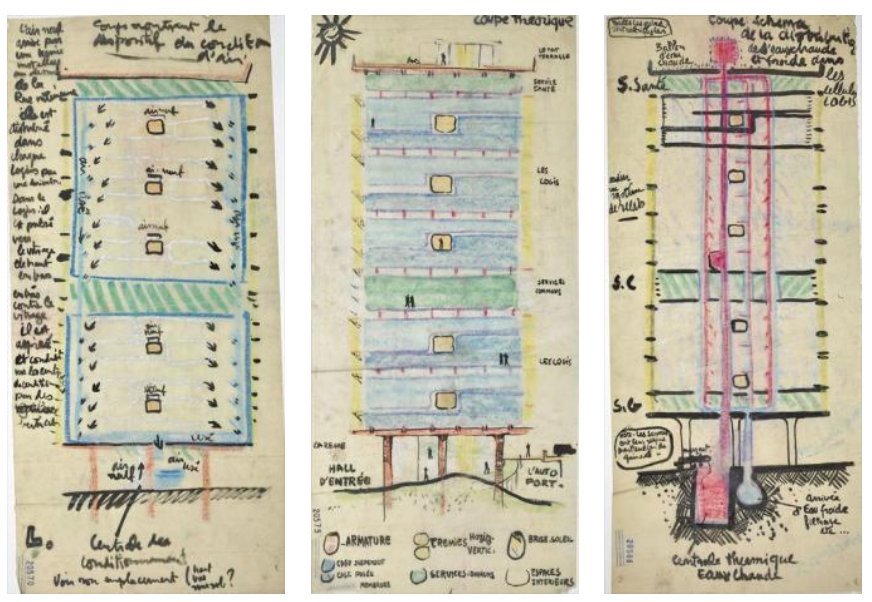

3. Analytical diagrams of Unite d'Habitation showing concern towards human comfort (Fondation Le Corbusier, image no. 20570, 20575 and 20586 @ FLC-ADAGP).

\section{Standard for architectural performance for well-being}

Further debates in architectural theories and practices have extensively questioned and criticized the approach of modern architecture that was mainly directed by standards and functional order, while human inhabitants have different social, cultural and behavioral needs and characteristics. 'The effect, as well as the aim, of this machinic metaphor is to denigrate the human subject. In Le Corbusier's work it is about stressing uniformity, regularity and function. ${ }^{28}$ There is a danger that such standardization may result in the ignorance of many humanistic aspect of architecture. The idea of architecture of machine was led to several generalizations: 'firstly, that a wellstated problem naturally finds its solution; secondly, that since all men have the same biological organization, they all have the same basic needs; and thirdly, that architecture, like machinery, should be a product of competitive selection applied to standards which, in turn, should be determined by logical analysis and experimentation. ${ }^{29}$

This criticism on the generalization embedded in the machine idea, however, was also countered by some arguments such as: 'modern architecture becomes a subject of humanism. ... Based upon the expression of rational conditions and functional needs, it became as independent, free and even emotional as any work ever created by man - therefore approachable from the humanistic point of view. ${ }^{30}$ This argument suggested the possibility to consider the position of architecture as machine from humanistic approach, rather than simply taking into account its mechanistic and standardized aspects. Understanding humanistic side of architecture becomes very important since the architecture and design also needs to have a role as an instrument of 'social engineering" that could impact on the improvement of the society and human behavior. ${ }^{31}$

This paper attempts to argue that within Le Corbusier's idea of architecture as machine, manifested through standardization, it is possible to situate the human body as an integral part of architecture as the machine for

\footnotetext{
${ }^{28} \mathrm{King}$, In dwelling: Implacability, exclusion and acceptance, p. 50

${ }^{29}$ Collins, Paul. Changing ideals in modern architecture 1750-1950. London: Faber and Faber, 1965, p. 165

${ }^{30}$ Zucker, Paul. "The humanistic approach to modern architecture," The Journal of Aesthetics and Art Criticism, vol. 2, no. 7, 1943 , p. 26

${ }^{31}$ Abel, Chris. Architecture, technology and process. London: Routledge, 2004, p. 63
} 
living. There seemed to be a relational interaction between human body and architecture beyond the standardized requirements of the dwelling. Le Corbusier clearly emphasized that the ultimate goal of the standards was to achieve human well-being: 'Where order reigns, well-being begins. ${ }^{32}$ The form language of modern architecture was essentially the attempts to link the expression of materiality of architecture with the well being of the buildings users. ${ }^{33}$ This was manifested mainly through formal language that emphasized on the spatial qualities that were conducive to human comfort, ergonomics and health. In other words, the standards became the way to guarantee the performance of architecture in functioning for human well-being.

The most often criticism against the idea of architecture as machine is that of the tendency of the machine to dehumanize. This is particularly attributed to the standards that tend to assume the same needs for every human. Standardization of architecture would lead to the standardization of human life. '...standardization became a way of life, where not only products and work processes were standardized for the first time but also people's daily routines, desires, and leisure activities. ...it failed to include the individual expression of consumers. ${ }^{, 34}$ In establishing the standards, Le Corbusier took position in understanding human needs within the context of modern life. This was done mainly by criticizing the spatial qualities that according to him were not appropriate to the modern living. He argued that the old way of living was no longer appropriate: 'the modern world we live in which has changed the whole manner in which humans should relate to the built environment. ${ }^{35}$ Thus architecture should also be designed in accordance to the new way of living, which Le Corbusier defined as the way of living that was more efficient and healthier.

It becomes necessary to address the issue of whether standardization of architecture could be assumed to fulfill the various needs of human. It is possible to examine whether there are any components of the dwelling that could be deemed as basic and general - thus assumed to be the same for all human being. There were some basic necessities that needed to be satisfied for all human organisms in order to survive, and these eventually led to the needs for controlling the environmental condition to fulfill these basic needs. ${ }^{36}$ Some requirements existed on how the dwelling should fulfill human needs at the most basic level of physiological comfort and health. Physiological comfort and health is something that could be explained scientifically, by referring to certain physical conditions of architecture that match the needs of comfort and health. Some examples in Le Corbusier's Manual of the Dwelling were: 'One wall to be entirely glazed, opening if possible on to a balcony for sun baths' and 'Demand ventilation panes to the windows in every room. ${ }^{37}$ These recommendations suggested the elements of architecture that were crucial to maintain physiological comfort and health of the inhabitants.

Thus the idea of human basic needs which Le Corbusier responded to by establishing the standards referred to human basic needs that could be assumed the same for every organisms - those that were related to basic physiological needs of comfort and health. This is where the standardization of architecture could play its important role, in defining the spatial quality that could not be compromised. Establishment of standards becomes possible (and also necessary) for certain aspects of architecture. These basic human needs are those that

\footnotetext{
${ }^{32}$ Le Corbusier, Towards a new architecture, p. 54

${ }^{33}$ Newman, "Whose failure is modern architecture?" p. 58

${ }^{34}$ Klingman, "Eyes, which do not see: Liners, airplanes, automobiles”, pp. 29-30

${ }^{35} \mathrm{King}$, In dwelling: Implacability, exclusion and acceptance, p. 48

${ }^{36}$ Broadbent, Geoffrey. Design in architecture: Architecture and the human sciences. London: David Fulton Publishers, 1988, p. 138-154.

${ }^{37}$ Le Corbusier, Towards a new architecture, p. 123
} 
are inevitable requirements towards human well-being, since they become the prerequisite before the other needs - that are more psychological, social, or cultural - could be fulfilled.

Le Corbusier, however, also established standards that were more relevant to the needs other than the basic physiological needs. For example, he recommended certain way of orderly living with no clutter and certain taste of art and aesthetics: 'Put only a few pictures and none but the good ones. Keep your odds and ends in drawers or cabinets. The gramophone or the pianola or the wireless will give you exact interpretation of first-rate music... ${ }^{38}$ These recommendations had different nature from those that intended to establish standards for physiological comfort and health. These seemed to be the standards that could be easily criticized since every human may have different understanding of what was orderly living and had different aesthetical taste. It is important to address this kind of recommendation wisely in order to leave enough rooms for individual aspiration, which is also important for human well-being.

The establishment of standards that became the important aspect in the idea of architecture as machine could be understood as Le Corbusier's attempts to generate architecture as a system to fulfill the functional needs of human being. Standards are necessary for some aspects of architecture that could not be compromised, especially those related to human physiological comfort, ergonomics and health, which were also a prerequisite for human well-being. Architecture as machine becomes a system that could promote the interaction between human body and architecture, through the establishment of standards. Standards were established not merely to achieve generalization or uniformity of architectural forms or to achieve cheap and quick production, but to ensure the performance of architecture that promotes human comfort, ergonomics and health. Architecture as machine is essentially a standardized systems of architecture, which were established for the ultimate purpose for the wellbeing of its inhabitants.

\section{Acknowledgements}

This paper was supported by the funding from Cluster Research Grant, Universitas Indonesia, 2015.

\section{Bibliography}

Abel, Chris: Architecture, technology and process. London: Routledge, 2004.

Banham, Reyner: "A home is not a house”. Art in America, vol. 2, 1965. pp. 70-79.

Broadbent, Geoffrey: Design in architecture: Architecture and the human sciences. London: David Fulton Publishers, 1988.

Benton, Charlotte: "Le Corbusier: Furniture and the interior," Journal of Design History, vol. 3, no. 2/3, 1990. pp. 103-124.

Campbell, Margaret: "What tuberculosis did for modernism: The Influence of a curative environment on modernist design and architecture," Medical History, vol. 49, 2005. pp. 463-488

Collins, Paul: Changing ideals in modern architecture 1750-1950. London: Faber and Faber, 1965.

Evenson, Norma: Le Corbusier: The machine and the grand design. London: Studio Vista, 1969.

Guattari, Felix: "On machines". Journal of Philosophy and the Visual Arts, vol. 6, 1995. pp. 8-12.

\footnotetext{
${ }^{38}$ Le Corbusier, Towards a new architecture, p. 123
} 
Ioannidou, Ersi. "Humanist machines: Daniel Libeskind's 'Three lessons in architecture'”. In Bandyopadhyay, Soumyen et al (Eds.) The humanities in architectural design: A contemporary and historical perspective. Routledge: London, 2010. pp. 81-90.

King, Peter: In dwelling: Implacability, exclusion and acceptance. Hampshire: Ashgate, 2008.

Le Corbusier: Towards a new architecture. New York: Dover Publication, 1986.

Mackenzie, Christopher: "Le Corbusier in the sun”, The Architectural Review, June 2011.

Newman, Oscar: "Whose failure is modern architecture?" In Mikellides, Byron (Ed.): Architecture for people. New York: Holt. Rinehart \& Winston, 1980. pp. 44-58.

Nicholson, Ben: Appliance house. MIT Press, 1990.

Rault, Jasmine: Eileen Gray and the design of sapphic modernity: Staying in. Surrey, England: Ashgate, 2011.

Smith, Wally \& Lewi, Hannah: "The magic of machines in the house," The Journal of Architecture, vol. 13, no. 5, pp. 633-660.

Tim Benton: "Pessac and Lege revisited: Standards, dimensions, and failures." In B. B. Taylor (ed.), Le Corbusier et Pessac. Paris: Fondation Le Corbusier, 1972.

Sully, Nicole: "Modern architecture and complaints about the weather, or, 'Dear Monsieur Le Corbusier, It is still raining in our garage...." M/C Journal, vol. 12, no. 4, 2009.

Von Moos, Stanislaus: Le Corbusier: Elements of a synthesis, Rotterdam: 010 Publishers, 2009.

Zucker, Paul: "The humanistic approach to modern architecture," The Journal of Aesthetics and Art Criticism, vol. 2, no. 7, 1943. pp. 21-26. 